ISSN 1392-3196 / e-ISSN 2335-8947

Zemdirbyste-Agriculture, vol. 100, No. 2 (2013), p. 119-126

DOI 10.13080/z-a.2013.100.015

\title{
Leaching of base cations as affected by a forty-year use of mineral fertilisation
}

\author{
Tomas ADOMAITIS, Gediminas STAUGAITIS, Jonas MAŽVILA, Zigmas VAIŠVILA, \\ Jonas ARBAČIAUSKAS, Jadvyga LUBYTĖ, Donatas ŠUMSKIS, Antanas ŠVĖGŽDA \\ Agrochemical Research Laboratory, Lithuanian Research Centre for Agriculture and Forestry \\ Savanoriu 287, Kaunas, Lithuania \\ E-mail: dirvotyra@agrolab.lt
}

\begin{abstract}
A long-term crop rotation experiment was established in Central Lithuania (Skėmiai, Radviliškis region) in 1971 (lysimeters were installed in 1976) on a sandy loamy Endocalcari-Endohypogleyic Cambisol (CMg- $n$-w-can). The effect of regular fertilisation with different rates and combinations of NPK fertilisers in a crop rotation (winter wheat $\rightarrow$ sugar beet $\rightarrow$ spring barley $\rightarrow$ spring rape $\rightarrow$ annual grasses and perennial grasses) on the concentrations of cations $\left(\mathrm{Ca}^{2+}, \mathrm{Mg}^{2+}, \mathrm{K}^{+}\right.$and $\left.\mathrm{Na}^{+}\right)$in lysimeter water, sampled at 40 and $80 \mathrm{~cm}$ depths during winter and summer periods, was investigated.

During the period 1976-2011, leaching of calcium was the most intensive one, followed by that of magnesium; leaching of sodium and potassium was significantly less. As a result of application of the $\mathrm{N}_{111} \mathrm{P}_{96} \mathrm{~K}_{96}$ fertilisation rates the sum of average concentrations of the base cations $\mathrm{Ca}^{2+}, \mathrm{Mg}^{2+}, \mathrm{Na}^{+}$and $\mathrm{K}^{+}$in lysimeter water at $40 \mathrm{~cm}$ depth was $179.58 \mathrm{mg} \mathrm{l}^{-1}$ in winter and $218.99 \mathrm{mg} \mathrm{l}^{-1}$ in summer (calcium -145 and $180 \mathrm{mg} \mathrm{l}^{-1}$, magnesium - 29 and $33 \mathrm{mg} \mathrm{l}^{-1}$, sodium -3.92 and $4.20 \mathrm{mg} \mathrm{l}^{-1}$, potassium -1.66 and $1.79 \mathrm{mg} \mathrm{l}^{-1}$, respectively). Average fertilisation rates $\left(\mathrm{N}_{111} \mathrm{P}_{96} \mathrm{~K}_{96}\right)$ increased the concentration of $\mathrm{Ca}^{2+}$ in lysimeter water by 1.4 times in winter and by 1.5 times in summer, while high rates $\left(\mathrm{N}_{222} \mathrm{P}_{192} \mathrm{~K}_{192}\right)$ - by 1.9 and 2.2 times, respectively. Mineral fertilisation resulted in 232-360 $\mathrm{kg} \mathrm{ha}^{-1} \mathrm{Ca}^{2+}$ leached each year into the deeper layers of soil. Phosphorus fertilisation makes the calcium balance in the soil less negative, while nitrogen and potassium fertilisation encourages the process of calcium leaching. The extent of magnesium leaching from the soils treated with mineral fertilisers was within the range of 31-56 $\mathrm{kg} \mathrm{ha}^{-1} \mathrm{Mg}^{2+}$ in winter and 17-30 kg ha-1 $\mathrm{Mg}^{2+}$ in summer. Average and high fertilisation rates increase the level of magnesium leaching by 1.5 and 2.5 times, respectively. Small amounts of potassium were leached into the $40 \mathrm{~cm}$ depth of light loamy soil: in not fertilised plots $0.93 \mathrm{~kg} \mathrm{ha}^{-1} \mathrm{~K}^{+}$in winter and $0.60 \mathrm{~kg} \mathrm{ha}^{-1} \mathrm{~K}^{+}$in summer, in plots treated with $\mathrm{N}_{111} \mathrm{P}_{96} \mathrm{~K}_{96}$ and $\mathrm{N}_{222} \mathrm{P}_{192} \mathrm{~K}_{192}-1.80$ and 0.95 , and 4.54 and $2.42 \mathrm{~kg} \mathrm{ha}^{-1} \mathrm{~K}^{+}$, respectively. Low levels of potassium leaching had little effect on potassium balance in the soil. Sodium leaching level did not exceed 7.67 $\mathrm{kg} \mathrm{ha}^{-1} \mathrm{Na}^{+}$in winter and $3.39 \mathrm{~kg} \mathrm{ha}^{-1} \mathrm{Na}^{+}$in summer. Application of mineral fertilisers resulted in sodium leaching increase by $5.77 \mathrm{~kg} \mathrm{ha}^{-1} \mathrm{Na}^{+}$on an average; potassium fertilisation encouraged the process of sodium leaching. As a result of intensive fertilisation the concentrations of calcium and magnesium ions in lysimeter water sampled at $80 \mathrm{~cm}$ depth were slightly higher than in the lysimeter water at $40 \mathrm{~cm}$ depth, the concentration of potassium ions - lower, and the concentration of sodium ions - about the same.
\end{abstract}

Key words: concentrations of $\mathrm{Ca}^{2+}, \mathrm{Mg}^{2+}, \mathrm{K}^{+}, \mathrm{Na}^{+}$, lysimeters, NPK fertilisers, soil.

\section{Introduction}

Calcium, magnesium, potassium and sodium are vitally important elements. These base elements (cations) are very important not only as plant nutrients; agrochemical and physical properties of soil depend on the base cations as well.

Calcium (Ca) is a constituent of more than 300 minerals. The most common calcium-containing minerals are calcite $\left(\mathrm{CaCO}_{3}\right)$, dolomite $\left(\mathrm{CaCO}_{3} \times \mathrm{MgCO}_{3}\right)$ and gypsum $\left(\mathrm{CaSO}_{4} \times 2 \mathrm{H}_{2} \mathrm{O}\right)$. Because it is dissolved in the soil solutions, calcium migrates into the deeper layers of soil in forms of ions, not dissociated molecules and colloids. Calcium improves soil properties and thus has a tremendous effect on the growth and development of plants as well as on soil microbial activity. Calcium predominates over other base cations in the soils of Lithuania. Calcaric soils contain the highest levels of calcium, yet even in acid soils its amount is $2-3$ times larger than that of potassium or phosphorus. Migration of calcium is conditioned by the soil colloids and the properties of soil sorption complex. Most soil colloids have negative charge; if they are not neutralised by potassium, sodium or magnesium, then calcium ions neutralise them. Calcium element is readily leached. The succession of vertical migration intensity of soil elements is as follows: $\mathrm{Na}>\mathrm{Ca}>\mathrm{Mg}>\mathrm{K}$ (Mažvila, 1998; Bruce, 1999).

Magnesium $(\mathrm{Mg})$ is most commonly found in different types of silicate minerals (dolomites, dolomite limestones) which are only very slightly soluble in water. Sometimes it occurs in a pure form of magnetite $\left(\mathrm{MgCO}_{3}\right)$. The level of magnesium (as well as other cations) content in soil depends strongly on soil texture. Coarse fractions of soil (sand and silt) are made of quartz; 
they contain large amounts of silicon and small amounts of calcium, magnesium, potassium and other elements. Fine fractions of soil (clay and colloids) are made of alumosilicates containing large amounts of aluminium, iron, calcium, magnesium, potassium, phosphorus, etc. Soils treated with magnesium containing lime fertilisers (dolomite powder, limestone powder) usually are high in magnesium. The exchangeable form of magnesium is of particular importance. It usually constitutes $5-10 \%$ of the total magnesium available in soil. Like calcium, magnesium improves the properties of soil, yet high levels of magnesium content impair soil water regime (Mažvila, 1998; Aitken, Scott, 1999).

Potassium $(\mathrm{K})$ is one of the most abundant constituents of the Earth's crust. Most potassium exists as a primary or secondary mineral; these minerals constitute a large part of clay fraction $(<2 \mu \mathrm{m})$. Soil potassium can be found in different forms; Barber (1984) grouped the soil potassium as follows: solution, exchangeable, captured and mineral potassium.

Sodium $(\mathrm{Na})$ occurs in silicate minerals. Soil sodium is readily leached; therefore soils (especially the lighter ones) are often low in sodium (Levy, Feigenbaum, 1997). Small amounts of sodium are found in plants and animals. Sodium is essential for the biochemical processes taking place in human body. Together with potassium, sodium regulates the amount of water in and around the body cells.

Calcium $\left(\mathrm{Ca}^{2+}\right)$ and magnesium $\left(\mathrm{Mg}^{2+}\right)$ cations are leached from the soil most intensively. The summarized data obtained from the long-term (1972-1995) lysimetric experiments conducted in Lithuania suggests that the amounts of calcium and magnesium leached from the soil depend not on the amount of water moving through the soil, but on the level of calcium and magnesium content in the soil, therefore the largest amounts of these elements are leached from heavy-textured calcaric soils (Tripolskaja, Janušienè, 2010). Lithuanian geologists suggest that the fertile layer of arable soils of Lithuania and Latvia loses 50-60\% of calcium and magnesium, and $10 \%$ of potassium (Kadūnas et al., 1999). Depending on the soil formation and soil texture, the annual amount of calcium lost by leaching is within the range of 77.7-258.6 $\mathrm{kg} \mathrm{ha}^{-1}$, magnesium - 15.8-112.7 $\mathrm{kg} \mathrm{ha}^{-1}$, potassium $6.5-43.4 \mathrm{~kg} \mathrm{ha}^{-1}$, sodium - 10.7-53.6 kg ha-1 (Tyla et al., 1997). Migration of ions in soils is also strongly affected by weather conditions, rates of organic, mineral fertilisers and liming materials applied as well by the species of agricultural crop (Erickson et al., 2005; Mesič et al., 2007; Патыка et al., 2009).

The research evidence presented by Tripolskaja (2005) suggests that during the six-year crop rotation 700 $750 \mathrm{~kg} \mathrm{ha}^{-1} \mathrm{Ca}$ was added to the soil when manure was applied; when soil was treated with manure and mineral fertiliser (calcium superphosphate), the amount of $\mathrm{Ca}$ added to the soil increased by about $150 \mathrm{~kg} \mathrm{ha}^{-1}$. Calcium $\left(\mathrm{Ca}^{2+}\right)$ concentration in lysimeter water increased by 27.6 and $25.4 \mathrm{mg} \mathrm{l}^{-1}$, respectively, when farmyard manure and liquid manure was applied. The highest concentration of calcium in lysimeter water $\left(65.2 \mathrm{mg} \mathrm{l}^{-1} \mathrm{Ca}^{2+}\right)$ was determined when soil was treated with both manure and mineral fertilisers. It was noticed that fertilisation increased the migration of magnesium in soil as well, but the concentrations of magnesium in lysimeter water were lower (on average $3.7-7.4 \mathrm{mg} \mathrm{l}^{-1}$ ), since magnesium is retained by soil particles more strongly than calcium. As a result of fertilisation, the concentrations of magnesium in lysimeter water increased by $2.6-3.7 \mathrm{mg} \mathrm{l}^{-1} \mathrm{Mg}^{2+}$.

The data obtained from the long-term (19922003) experiments conducted in Western Lithuania suggests that the largest annual amounts (on average $112.7 \mathrm{~kg} \mathrm{ha}^{-1}$ ) of calcium were leached from the limed experimental plots treated with mineral and organic fertilisers; the amounts of calcium leached from these plots were larger by $21.3 \%$ than those of calcium leached from the not limed and not fertilised experimental plots (Končius et al., 2008).

Potassium leaching rates from the arable soil layer are low compared to those of calcium and magnesium (Мотузова и др., 2009). Alfaro et al. (2004) indicate that an average annual potassium leaching rate is $6 \mathrm{~kg} \mathrm{ha}^{-1}$ in sandy loam soils and $13 \mathrm{~kg} \mathrm{ha}^{-1}$ in clay soils. The data obtained by Mašauskas and Mašauskienè (2010) from the experiments conducted on sandy loam Cambisol suggests that an average annual potassium leaching rate is $9.4-10.0 \mathrm{~kg} \mathrm{ha}^{-1}$ in fertilised soil and $7.5 \mathrm{~kg} \mathrm{ha}^{-1}$ in not fertilised soil. Potassium leaching rate dependence on the soil type was investigated; the highest concentration of potassium $\left(10.9 \mathrm{mg} \mathrm{l}^{-1}\right)$ was determined in lysimeter water collected from Eutri-Haplic Arenosol (ARh-eu), and the lowest (2.2-4.9 $\left.\mathrm{mg} \mathrm{l}^{-1}\right)$ - in Calcaric Luvisol (LVk) and Cambisol (CM) (loamy topsoil, clay subsoil) (Tyla et al., 1997). Higher levels of calcium content in soil stimulate the process of potassium leaching (Kolahchi, Jalali, 2007).

The levels of sodium content in the soils of Lithuania are lower than those of potassium, yet sodium leaching rates are higher by $2-3$ times. Sodium concentration is soil solution increases when sodiumcontaining potassium fertiliser is applied. The largest amounts of sodium are leached from Orthidystric Albeluvisol (ABd-o), from Calcaric and Haplic Luvisol (LVk and LVh) (Tyla et al., 1997).

The aim of the long-term lysimeter experiments was to investigate the effect of regular fertilisation with different rates and combinations of NPK fertilisers on the leaching of base cations $\left(\mathrm{Ca}^{2+}, \mathrm{Mg}^{2+}, \mathrm{K}^{+}, \mathrm{Na}^{+}\right)$from the calcaric sandy loams of Central Lithuania.

\section{Materials and methods}

Our research was conducted during 1976-2011 within a framework of a complex long-term fertilisation experiment established in 1971 on a sandy loamy Endocalcari-Endohypogleyic Cambisol (CMg-n-w-can). Genetic soil horizons are composed predominantly of sand $(2.0-0.05 \mathrm{~mm})$ fraction $(54.7-70.1 \%)$ with lesser amounts of silt $(0.05-0.002 \mathrm{~mm}, 23.3-31.2 \%)$ and clay $(<0.002 \mathrm{~mm}, 12.4-15.0 \%)$ fractions. Leaching of clay particles from the humus-rich Ap horizon into the $\mathrm{Bw}$ horizon is insignificant - the amount of clay particles $(<0.002 \mathrm{~mm})$ in Bw horizon was only $0.9 \%$ higher than in humus-rich Ap horizon. Before the experiment, the soil $\mathrm{pH}$ of the arable layer (Ap) was close to neutral $\left(\mathrm{pH}_{\mathrm{KCl}}\right.$ 6.8-7.1) (potentiometric method), humus content 2.2$2.4 \%$ (Tyurin method), $\mathrm{N}_{\text {tot }}-0.17 \%$ (Kjeldahl method), plant available phosphorus $\left(\mathrm{P}_{2} \mathrm{O}_{5}\right)-57-90 \mathrm{mg} \mathrm{kg}^{-1}$ and potassium $\left(\mathrm{K}_{2} \mathrm{O}\right)-109-112 \mathrm{mg} \mathrm{kg}^{-1}$ (A-L method). Subsoil horizon was slightly alkaline, containing somewhat more of plant available phosphorus (82-115 $\mathrm{mg} \mathrm{kg}^{-1}$ ) and less of plant available potassium $\left(60-87 \mathrm{mg} \mathrm{kg}^{-1}\right)$. 
The following crop rotation was applied: winter wheat $(1974,1980,1983,1987,1994,1996,1998,2002$, 2006 and 2010), sugar beet (1971, 1975, 1981, 1984, 1999 and 2003), spring barley (1972, 1985, 1988, 1995, 2000, 2004, and 2008), annual grasses (1973, 1976, 1982, 1986, 1997, 2001, 2005 and 2009), perennial grasses (1977-1979 and 1989-1993), and spring rape (2007 and 2011).

Specific nitrogen, phosphorus and potassium fertilisation rates for cereals, annual grasses and rape as well as phosphorus and potassium fertilisation rates for perennial grasses depended on the treatment of the experiment and were within the range of $90-180 \mathrm{~kg} \mathrm{ha}^{-1}\left(120-240 \mathrm{~kg} \mathrm{ha}^{-1}\right.$ for sugar beet). Specific nitrogen fertilisation rates for perennial grasses for each cut were within the range of 60 $120 \mathrm{~kg} \mathrm{ha}^{-1}$. Average annual fertilisation rates for the whole experimental period were as follows: nitrogen - 111$222 \mathrm{~kg} \mathrm{ha}^{-1}$, phosphorus - 96-192 $\mathrm{kg} \mathrm{ha}^{-1}$ and potassium - 96-192 $\mathrm{kg} \mathrm{ha}^{-1}$. Ammonium nitrate, superphosphate and potassium chloride fertilisers were used. Phosphorus and potassium contents in fertilisers and in soil are presented as oxides $\left(\mathrm{P}_{2} \mathrm{O}_{5}\right.$ and $\left.\mathrm{K}_{2} \mathrm{O}\right)$.

Lysimeters of ilova (Шилова, 1955) type with a lysimeter screen size of $40 \times 57 \mathrm{~cm}$ and receiver capacity of 3 litres, were installed in 1976 at $40 \mathrm{~cm}$ depth in the test plots of two repetitions of the following nine treatments: $\mathrm{N}_{0} \mathrm{P}_{0} \mathrm{~K}_{0}, \mathrm{~N}_{0} \mathrm{P}_{96} \mathrm{~K}_{96}, \mathrm{~N}_{111} \mathrm{P}_{0} \mathrm{~K}_{96}, \mathrm{~N}_{111} \mathrm{P}_{96} \mathrm{~K}_{0}$, $\mathrm{N}_{111} \mathrm{P}_{96} \mathrm{~K}_{96}, \mathrm{~N}_{0} \mathrm{P}_{192} \mathrm{~K}_{192}, \mathrm{~N}_{222} \mathrm{P}_{0} \mathrm{~K}_{192}, \mathrm{~N}_{222} \mathrm{P}_{192} \mathrm{~K}_{0}, \mathrm{~N}_{222} \mathrm{P}_{192} \mathrm{~K}_{192}$, and at $80 \mathrm{~cm}$ depth in the test plots of two repetitions of the following four treatments: $\mathrm{N}_{0} \mathrm{P}_{0} \mathrm{~K}_{0}, \mathrm{~N}_{111} \mathrm{P}_{96} \mathrm{~K}_{96}$, $\mathrm{N}_{0} \mathrm{P}_{192} \mathrm{~K}_{192}, \mathrm{~N}_{222} \mathrm{P}_{192} \mathrm{~K}_{192}$.

The Selyaninov's hydrothermal coefficient (HTC) was used for evaluation of meteorological conditions (Хомяков, 1989); it was calculated using the following equation:

$\mathrm{HTC}=\Sigma \mathrm{p} \times(0.1 \times \Sigma \mathrm{t})^{-1}$, where $\Sigma \mathrm{p}$ is a sum of precipitation in V, VI, VII, VIII and IX months, when the temperature is $>+10^{\circ} \mathrm{C}, \Sigma \mathrm{t}-$ a sum of active $\left(>+10^{\circ} \mathrm{C}\right)$ air temperatures of the same period.

During the period of our research a moderate drought (HTC 0.68 and 0.57) was recorded in 1992 and 2002; mild drought (HTC 0.8-0.9) in 1982, 1983, 1991, 1999, 2003 and 2008, normally humid season (HTC 1.0-1.5) in 1976-1979, 1984, 1985, 1988-1990, 1994-1997, 2001-2007, 2009 and 2011, humid season (HTC 1.6-1.77) in 1981, 1986, 1987, 1993, 1998, 2000 and 2010, and excessively humid season (HTC 2.24) in 1980. During the cold period of a year (October-May) an average precipitation rate in months of October, December, January and February was 48.1, 44.8, 39.2 and $27.9 \mathrm{~mm}$, respectively $(4.6,1.8,15.3$ and $11.6 \%$ higher than multiannual average), in April and November - 34.8 and $43.8 \mathrm{~mm}$ (10.8\% and $20.4 \%$ lower than multiannual average), in March - close to multiannual average. The mean precipitation sum was $209 \mathrm{~mm}(115-306 \mathrm{~mm})$ for cold period, and $340 \mathrm{~mm}(160-457 \mathrm{~mm})$ - for warm period of a year. In comparison to the multiannual average, the average positive air temperature was by $+1.1^{\circ} \mathrm{C}$ higher in April, by $+2.4^{\circ} \mathrm{C}$ higher in October, by $-0.3--2.0^{\circ} \mathrm{C}$ lower in December - March, and the same - in November.

Lysimeter water samples were taken in spring before fertilisation and sowing (April-May) and in autumn after harvesting (September-December).
The amounts $\left(\mathrm{kg} \mathrm{ha}^{-1}\right)$ of leached cations were calculated by multiplying the average concentration (mg $1^{-1}$ ) of the element in lysimeter water by the precipitation rate $\left(\mathrm{m}^{3} \mathrm{ha}^{-1}\right)$ of a particular year and by the runoff coefficient. This coefficient was determined in the Central Lithuania's lowlands, near Kèdainiai city; it is 0.52 for winter period and 0.16 - for summer period (Baigys, Gaigalis, 2012). The weighted average $(\bar{x})$ and the standard deviation $(s)$ of the average concentration of the elements was calculated using the following equations:

$$
\bar{x}=\frac{\sum x_{i} f_{i}}{\sum f_{i}}, s=\sqrt{\frac{\sum(x-\bar{x})^{2}}{(n-1)}}, \text { where } x \text { is con- }
$$

centration of element $\left(\mathrm{mg} \mathrm{l}^{-1}\right), f$ - precipitation rate $(\mathrm{mm})$, $\mathrm{n}$ - number of water samples.

The samples of soil, plants and water were analysed in the specialised laboratories of the Agrochemical Research Laboratory of the Lithuanian Research Centre for Agriculture and Forestry. Calcium and magnesium content was determined using flame atomic absorption spectrometric method, potassium and sodium - using flame emission spectrometric method. Content of different elements in soil was determined using $0.1 \mathrm{M} \mathrm{BaCl}_{2}$ extraction, in plant material - by combustion at $450 \pm 50^{\circ} \mathrm{C}$; the ash obtained from the combustion was dissolved in $20 \% \mathrm{HCl}$ solution.

The experimental data were statistically processed using analysis of variance and correlationregression analysis methods employing software the $S T A T$ and $A N O V A$ programmes of statistical data processing and applying the $F$ criteria (Clewer, Scarisbrick, 2001).

\section{Results and discussion}

After 41 years of regular fertilisation the following composition of exchangeable alkali cations was determined in the humus-containing layer $(0-29 \mathrm{~cm})$ of the sandy loamy Endocalcari-Endohypogleyic Cambisol: calcium $\left(\mathrm{Ca}^{2+}\right)-127-159 \mathrm{mmol}+\mathrm{kg}^{-1}$ (predominant cation), magnesium $\left(\mathrm{Mg}^{2+}\right)-16.1-21.0 \mathrm{mmol}+\mathrm{kg}^{-1}$, potassium $\left(\mathrm{K}^{+}\right)-1.54-3.49 \mathrm{mmol}+\mathrm{kg}^{-1}$ and sodium $\left(\mathrm{Na}^{+}\right)-1.31-1.91 \mathrm{mmol}+\mathrm{kg}^{-1}$. The $30-50 \mathrm{~cm}$ soil layer (subsoil) in comparison to the top layer contained significantly larger amounts of exchangeable calcium, smaller amounts of exchangeable potassium and similar amounts of exchangeable magnesium and sodium (Table 1).

Long-term fertilisation had no regular effect on the amounts of exchangeable magnesium and sodium in the humus-containing soil layer and in the subsoil; the levels of calcium in $0-29 \mathrm{~cm}$ soil layer slightly increased when plants were treated with average and high NPK fertilisation rates. NPK fertilisation increased the levels of exchangeable potassium in the soil by 1.5 times, while the application of NP fertilisers (without potassium fertiliser) resulted in slightly decreased levels of potassium in the soil - crop productivity was increased and therefore larger amounts of potassium (compared to the not fertilised plots) were taken up by the plants (Table 2 ). The total concentration of cations in the humuscontaining soil layer was higher when average and high NPK fertilisation rates were applied. This increase was mainly caused by the higher levels of calcium and potassium cations. 
Table 1. The amount of exchangeable cations in the soil

Skėmiai, Radviliškis region, 2011

\begin{tabular}{|c|c|c|c|c|c|c|c|c|c|c|c|c|}
\hline \multirow{2}{*}{\multicolumn{3}{|c|}{$\begin{array}{l}\text { Average fertilisation rate } \\
\qquad \mathrm{kg} \mathrm{ha}^{-1}\end{array}$}} & \multicolumn{10}{|c|}{ Soil layer $\mathrm{cm}$} \\
\hline & & & $0-29$ & $30-50$ & $0-29$ & $30-50$ & $0-29$ & $30-50$ & $0-29$ & $30-50$ & $0-29$ & $30-50$ \\
\hline \multirow{2}{*}{$\mathrm{N}$} & \multirow{2}{*}{$\mathrm{P}_{2} \mathrm{O}_{5}$} & \multirow{2}{*}{$\mathrm{K}_{2} \mathrm{O}$} & \multicolumn{2}{|c|}{$\mathrm{Ca}^{2+}$} & \multicolumn{2}{|c|}{$\mathrm{Mg}^{2+}$} & \multicolumn{2}{|c|}{$\mathrm{K}^{+}$} & \multicolumn{2}{|c|}{$\mathrm{Na}^{+}$} & \multicolumn{2}{|c|}{ sum of cations } \\
\hline & & & \multicolumn{10}{|c|}{$\mathrm{mmol}+\mathrm{kg}^{-1}$} \\
\hline 0 & 0 & 0 & 137 & 335 & 20.0 & 17.3 & 1.83 & 1.39 & 1.28 & 2.20 & 160.1 & 355.9 \\
\hline 0 & 96 & 96 & 139 & 323 & 19.2 & 17.0 & 2.27 & 1.32 & 1.57 & 1.61 & 162.0 & 342.9 \\
\hline 111 & 0 & 96 & 139 & 414 & 20.1 & 16.2 & 2.96 & 1.44 & 1.91 & 1.94 & 164.0 & 433.6 \\
\hline 111 & 96 & 0 & 127 & 181 & 16.1 & 14.4 & 1.54 & 1.31 & 1.50 & 1.53 & 146.1 & 198.2 \\
\hline 111 & 96 & 96 & 151 & 316 & 18.6 & 16.1 & 2.34 & 1.55 & 1.85 & 1.74 & 173.8 & 335.4 \\
\hline 0 & 192 & 192 & 136 & 321 & 18.3 & 16.8 & 3.49 & 1.67 & 1.31 & 1.72 & 159.1 & 341.2 \\
\hline 222 & 0 & 192 & 133 & 286 & 21.0 & 21.5 & 2.87 & 1.64 & 1.61 & 1.39 & 158.5 & 310.5 \\
\hline 222 & 192 & 0 & 139 & 251 & 19.8 & 16.6 & 1.83 & 1.54 & 1.79 & 2.09 & 162.4 & 271.2 \\
\hline \multirow[t]{2}{*}{222} & 192 & 192 & 159 & 304 & 17.3 & 18.2 & 2.87 & 1.82 & 1.63 & 1.48 & 180.8 & 325.5 \\
\hline & \multicolumn{2}{|c|}{$\mathrm{LSD}_{05}$} & 15.0 & 31.4 & 2.19 & 1.98 & 0.215 & 0.163 & 0.179 & 0.194 & 18.18 & 37.58 \\
\hline
\end{tabular}

Table 2. The accumulation of calcium, magnesium, potassium and sodium in the crop yield as affected by long-term fertilisation

Skėmiai, Radviliškis region, 1971-2011

\begin{tabular}{|c|c|c|c|c|c|c|c|c|c|c|}
\hline \multicolumn{3}{|c|}{$\begin{array}{l}\text { Average fertilisation rate } \\
\mathrm{kg} \mathrm{ha}^{-1}\end{array}$} & \multicolumn{8}{|c|}{$\begin{array}{l}\text { Accumulated in yield } \\
\mathrm{kg} \mathrm{ha}^{-1}\end{array}$} \\
\hline \multirow{2}{*}{$\mathrm{N}$} & \multirow{2}{*}{$\mathrm{P}_{2} \mathrm{O}_{5}$} & \multirow{2}{*}{$\mathrm{K}_{2} \mathrm{O}$} & \multicolumn{4}{|c|}{ during 41-year period } & \multicolumn{4}{|c|}{ annual average } \\
\hline & & & $\mathrm{Ca}$ & $\mathrm{Mg}$ & $\mathrm{K}$ & $\mathrm{Na}$ & $\mathrm{Ca}$ & $\mathrm{Mg}$ & $\mathrm{K}$ & $\mathrm{Na}$ \\
\hline 0 & 0 & 0 & 812 & 271 & 2140 & 115 & 19.8 & 6.6 & 52.2 & 2.8 \\
\hline 0 & 96 & 96 & 1119 & 369 & 3309 & 152 & 27.3 & 9.0 & 80.7 & 3.7 \\
\hline 111 & 0 & 96 & 1345 & 414 & 4289 & 168 & 32.8 & 10.1 & 104.6 & 4.1 \\
\hline 111 & 96 & 0 & 1460 & 451 & 3165 & 184 & 35.6 & 11.0 & 77.2 & 4.5 \\
\hline 111 & 96 & 96 & 1820 & 570 & 4727 & 221 & 44.4 & 13.9 & 115.3 & 5.4 \\
\hline 0 & 192 & 192 & 1168 & 381 & 3805 & 160 & 28.5 & 9.3 & 92.8 & 3.9 \\
\hline 222 & 0 & 192 & 1501 & 443 & 5232 & 180 & 36.6 & 10.8 & 127.6 & 4.4 \\
\hline 222 & 192 & 0 & 1660 & 484 & 3362 & 193 & 40.5 & 11.8 & 82.0 & 4.7 \\
\hline 222 & 192 & 192 & 2169 & 648 & 6753 & 258 & 52.9 & 15.8 & 164.7 & 6.3 \\
\hline
\end{tabular}

The concentrations of calcium and magnesium cations in lysimeter water predominate over the other cations. Leaching intensity of base cations depended on the mineral fertilisation rates. When average nitrogen $\left(\mathrm{N}_{111}\right)$, phosphorus $\left(\mathrm{P}_{96}\right)$ and potassium $\left(\mathrm{K}_{96}\right)$ fertilisation rates were applied using different combinations of NPK fertilisers, an annual average concentration of $\mathrm{Ca}^{2+}$ ions in lysimeter water sampled in winter period at $40 \mathrm{~cm}$ depth was $128-147 \mathrm{mg} \mathrm{l}^{-1}$; it was by $26-45 \mathrm{mg} \mathrm{l}^{-1}$ higher than in lysimeter water sampled from the not fertilised test plots. When the fertilisation rates were twice higher, the concentration of $\mathrm{Ca}^{2+}$ ions was $180-196 \mathrm{mg} \mathrm{l}^{-1}$ (application of fertilisers increased it by $78-94 \mathrm{mg} \mathrm{l}^{-1}$ ). Calcium concentration in lysimeter water sampled in summer period was higher than in winter: $175-184$ and 200-273 $\mathrm{mg} \mathrm{l}^{-1}$, respectively (application of fertilisers increased it by 56-65 and 81-154 $\mathrm{mg} \mathrm{l}^{-1}$, respectively) (Table 3). High phosphorus fertiliser (granulated superphosphate) rates $\left(\mathrm{P}_{192}\right)$ increased the concentration of calcium in lysimeter water (plants assimilated only $8 \%$ of calcium added to the soil with fertiliser). Average phosphorus fertiliser rates $\left(\mathrm{P}_{96}\right)$ had no significant effect on the concentration of calcium in lysimeter water (plants assimilated 16\% of calcium added to the soil with fertiliser). Adsorption processes of exchangeable cations could also affect the intensity of $\mathrm{Ca}^{2+}$ ions leaching: potassium and ammonium ions extrude the calcium ions from the soil adsorption complex into the soil solution, and then calcium is readily leached. These ions are also calcium antagonists - they prevent calcium from being taken up by plants, thus even larger amounts of calcium can be leached out from the soil.
Calcium concentration in lysimeter water was essentially dependent on nitrogen $\left(r^{2}=0.58, P>0.05\right)$ and on potassium $\left(r^{2}=0.79, P>0.01\right)$ fertilisation (Table 4$)$. Similar results were obtained by Poss and Saragoni (1992): when $75 \mathrm{~kg} \mathrm{ha}^{-1}$ potassium fertilisation was applied, the dependence of calcium concentration in lysimeter water on potassium ions in soil was $r^{2}=0.67$, and when potassium fertiliser was not applied $-r^{2}=0.24$.

Our research data suggests that annual calcium leaching rate is $232-360 \mathrm{~kg} \mathrm{ha}^{-1} \mathrm{Ca}$ when high fertilisation rates are used. Similar amounts (up to $320 \mathrm{~kg} \mathrm{ha}^{-1}$ ) of leached calcium were obtained in the experiments conducted by de Oliveira et al. (2002). Due to the increased water penetration through the soil during the cold period of a year, calcium leaching rates in that period are by 1.4-1.7 times higher than in summer. Granulated superphosphate fertiliser contains approximately $21 \%$ calcium, thus annual calcium supply to the soil was up to $202 \mathrm{~kg} \mathrm{ha}^{-1} \mathrm{Ca}$; still the balance of calcium in soil was negative. Application of nitrogen and potassium fertilisers increased the leaching of calcium. Magnesium levels in sandy loam Cambisol are approximately five times lower than calcium levels, therefore the leaching rates of magnesium are lower as well. When $\mathrm{N}_{111} \mathrm{P}_{96} \mathrm{~K}_{96}$ and $\mathrm{N}_{222} \mathrm{P}_{192} \mathrm{~K}_{192}$ fertilisation rates were applied, $\mathrm{Mg}^{2+}$ concentration in lysimeter water sampled in winter at $40 \mathrm{~cm}$ depth was 29 and $37 \mathrm{mg} \mathrm{l}^{-1}$, respectively, and in summer - 33 and $45 \mathrm{mg} \mathrm{l}^{-1}$, respectively; thus an average annual leaching rate was 31 and 43, and 17 and $24 \mathrm{~kg} \mathrm{ha}^{-1}$, respectively (Table 5). Other Lithuanian researchers indicate that magnesium leaching rates depend on the type of soil and are in the range of 9.4$156.8 \mathrm{~kg} \mathrm{ha}^{-1}$ (Tripolskaja, Janušienè, 2010). The data 
Table 3. The concentration of calcium $\left(\mathrm{Ca}^{2+}\right)$ in lysimeter water and leaching of calcium as affected by mineral fertilisation

Skèmiai, Radviliškis region, 1976-2011

\begin{tabular}{|c|c|c|c|c|c|c|c|c|c|}
\hline \multirow{2}{*}{\multicolumn{3}{|c|}{$\begin{array}{l}\text { Average fertilisation rate } \\
\mathrm{kg} \mathrm{ha}^{-1}\end{array}$}} & \multirow{2}{*}{\multicolumn{2}{|c|}{ Winter }} & \multirow{2}{*}{\multicolumn{2}{|c|}{$\begin{array}{c}\text { Summer } \\
\mathrm{Ca}^{2+} \\
\end{array}$}} & \multirow{2}{*}{\multicolumn{2}{|c|}{ Annual }} & \multirow{3}{*}{$\begin{array}{l}\text { Calcium } \\
\text { balance } \\
\mathrm{kg} \mathrm{ha}^{-1}\end{array}$} \\
\hline & & & & & & & & & \\
\hline $\mathrm{N}$ & $\mathrm{P}_{2} \mathrm{O}_{5}$ & $\mathrm{~K}_{2} \mathrm{O}$ & $\begin{array}{c}\text { concentration } \\
\mathrm{mg} \mathrm{l}^{-1}\end{array}$ & $\begin{array}{c}\text { leaching } \\
\mathrm{kg} \mathrm{ha}^{-1}\end{array}$ & $\begin{array}{c}\text { concentration } \\
\mathrm{mg} \mathrm{l}^{-1}\end{array}$ & $\begin{array}{c}\text { leaching } \\
\mathrm{kg} \mathrm{ha}^{-1}\end{array}$ & $\begin{array}{c}\text { concentration } \\
\mathrm{mg} \mathrm{l}^{-1}\end{array}$ & $\begin{array}{l}\text { leaching } \\
\mathrm{kg} \mathrm{ha}^{-1}\end{array}$ & \\
\hline \multicolumn{10}{|c|}{ at $40 \mathrm{~cm}$ depth } \\
\hline 0 & 0 & 0 & $102 \pm 40$ & 111 & $119 \pm 49$ & 65 & $111 \pm 59$ & 179 & -178 \\
\hline 0 & 96 & 96 & $128 \pm 47$ & 139 & $184 \pm 93$ & 94 & $158 \pm 100$ & 233 & -159 \\
\hline 111 & 0 & 96 & $134 \pm 31$ & 144 & $175 \pm 78$ & 93 & $157 \pm 87$ & 232 & -265 \\
\hline 111 & 96 & 0 & $147 \pm 42$ & 160 & $179 \pm 87$ & 94 & $165 \pm 91$ & 254 & -189 \\
\hline 111 & 96 & 96 & $145 \pm 31$ & 158 & $180 \pm 101$ & 106 & $173 \pm 102$ & 256 & -199 \\
\hline 0 & 192 & 192 & $180 \pm 62$ & 195 & $259 \pm 105$ & 143 & $217 \pm 131$ & 338 & -164 \\
\hline 222 & 0 & 192 & $182 \pm 53$ & 210 & $226 \pm 90$ & 123 & $211 \pm 102$ & 333 & -370 \\
\hline 222 & 192 & 0 & $182 \pm 53$ & 196 & $200 \pm 99$ & 110 & $198 \pm 100$ & 306 & -144 \\
\hline 222 & 192 & 192 & $196 \pm 73$ & 216 & $273 \pm 145$ & 144 & $241 \pm 155$ & 360 & -211 \\
\hline \multicolumn{3}{|c|}{$\mathrm{LSD}_{05}$} & 21.8 & 24.5 & 28.7 & 15.3 & 25.5 & 38.9 & \\
\hline \multicolumn{10}{|c|}{ at $80 \mathrm{~cm}$ depth } \\
\hline 0 & 0 & 0 & $113 \pm 30$ & 123 & $132 \pm 49$ & 71 & $123 \pm 57$ & 194 & -214 \\
\hline 111 & 96 & 96 & $152 \pm 37$ & 165 & $193 \pm 102$ & 106 & $175 \pm 103$ & 271 & -214 \\
\hline 0 & 192 & 192 & $217 \pm 57$ & 217 & $219 \pm 89$ & 121 & $220 \pm 98$ & 338 & -164 \\
\hline 222 & 192 & 192 & $236 \pm 56$ & 260 & $279 \pm 123$ & 149 & $258 \pm 127$ & 409 & -260 \\
\hline \multicolumn{3}{|c|}{$\mathrm{LSD}_{05}$} & 26.3 & 28.0 & 29.6 & 16.0 & 27.3 & 42.5 & \\
\hline
\end{tabular}

Table 4. The cation concentration in lysimeter water as influenced by mineral fertilisation

Skèmiai, Radviliškis region, 1976-2011

\begin{tabular}{ccccc}
\hline \multirow{2}{*}{ Fertiliser } & $\mathrm{Ca}^{2+}$ & $\mathrm{Mg}^{2+}$ & $\mathrm{K}^{+}$ & $\mathrm{Na}^{+}$ \\
\cline { 2 - 5 } & \multicolumn{5}{c}{$r^{2}$} \\
\hline Nitrogen $(\mathrm{N})$ & $0.58^{*}$ & 0.44 & 0.29 & 0.12 \\
Phosphorus $\left(\mathrm{P}_{2} \mathrm{O}_{5}\right)$ & $0.82^{* *}$ & 0.49 & 0.30 & 0.31 \\
Potassium $\left(\mathrm{K}_{2} \mathrm{O}\right)$ & $0.79^{* *}$ & $0.59^{*}$ & $0.97^{* *}$ & $0.91^{* *}$ \\
\hline
\end{tabular}

$*-P<0.05, * *-P<0.01$ obtained from the 12-year long experiment conducted in the Ukraine on sandy loam soils suggests that leaching loss of magnesium is 23-28 kg ha-1 (Патыка et al., 2009). Our research evidence suggests that application of average fertilisation rates increased the annual leaching rates of magnesium by $13-17 \mathrm{~kg} \mathrm{ha}^{-1}$, and high rates by $22-51 \mathrm{~kg} \mathrm{ha}^{-1}$. High potassium fertilisation rates (192 $\left.\mathrm{kg} \mathrm{ha}^{-1}\right)$ increased the leaching of magnesium $\left(r^{2}=0.59\right.$, $P>0.05)$. An average annual concentration of calcium and magnesium in lysimeter water at $80 \mathrm{~cm}$ depth was higher than that at $40 \mathrm{~cm}$ depth in the test plots where higher fertilisation rates were applied.

Table 5. The concentration of magnesium $\left(\mathrm{Mg}^{2+}\right)$ in lysimeter water and leaching of magnesium as affected by mineral fertilisation

Skèmiai, Radviliškis region, 1976-2011

\begin{tabular}{|c|c|c|c|c|c|c|c|c|}
\hline \multirow{2}{*}{\multicolumn{3}{|c|}{$\begin{array}{l}\text { Average fertilisation rate } \\
\mathrm{kg} \mathrm{ha}^{-1}\end{array}$}} & \multirow{2}{*}{\multicolumn{2}{|c|}{ Winter }} & \multirow{2}{*}{\multicolumn{2}{|c|}{$\frac{\text { Summer }}{\mathrm{Mg}^{2+}}$}} & \multirow{2}{*}{\multicolumn{2}{|c|}{ Annual }} \\
\hline & & & & & & & & \\
\hline $\mathrm{N}$ & $\mathrm{P}_{2} \mathrm{O}_{5}$ & $\mathrm{~K}_{2} \mathrm{O}$ & $\begin{array}{c}\text { concentration } \\
\mathrm{mg} \mathrm{l}^{-1}\end{array}$ & $\begin{array}{l}\text { leaching } \\
\mathrm{kg} \mathrm{ha}^{-1}\end{array}$ & $\begin{array}{c}\text { concentration } \\
\mathrm{mg} \mathrm{l}^{-1}\end{array}$ & $\begin{array}{l}\text { leaching } \\
\mathrm{kg} \mathrm{ha}^{-1}\end{array}$ & $\begin{array}{c}\text { concentration } \\
\mathrm{mg} \mathrm{l}^{-1}\end{array}$ & $\begin{array}{l}\text { leaching } \\
\mathrm{kg} \mathrm{ha}^{-1}\end{array}$ \\
\hline \multicolumn{9}{|c|}{ at $40 \mathrm{~cm}$ depth } \\
\hline 0 & 0 & 0 & $21 \pm 9$ & 23 & $24 \pm 11$ & 12 & $23 \pm 13$ & 35 \\
\hline 0 & 96 & 96 & $29 \pm 20$ & 31 & $34 \pm 19$ & 17 & $32 \pm 20$ & 48 \\
\hline 111 & 0 & 96 & $30 \pm 11$ & 31 & $37 \pm 15$ & 19 & $34 \pm 18$ & 50 \\
\hline 111 & 96 & 0 & $32 \pm 17$ & 35 & $33 \pm 19$ & 17 & $32 \pm 20$ & 52 \\
\hline 111 & 96 & 96 & $29 \pm 11$ & 31 & $33 \pm 17$ & 17 & $31 \pm 18$ & 48 \\
\hline 0 & 192 & 192 & $32 \pm 15$ & 35 & $42 \pm 22$ & 22 & $38 \pm 25$ & 57 \\
\hline 222 & 0 & 192 & $52 \pm 26$ & 56 & $57 \pm 31$ & 30 & $55 \pm 34$ & 86 \\
\hline 222 & 192 & 0 & $33 \pm 11$ & 37 & $38 \pm 18$ & 20 & $36 \pm 20$ & 57 \\
\hline 222 & 192 & 192 & $37 \pm 17$ & 40 & $45 \pm 27$ & 24 & $41 \pm 27$ & 67 \\
\hline \multicolumn{3}{|c|}{$\mathrm{LSD}_{05}$} & 4.5 & 4.9 & 5.5 & 2.8 & 5.0 & 7.8 \\
\hline \multicolumn{9}{|c|}{ at $80 \mathrm{~cm}$ depth } \\
\hline 0 & 0 & 0 & $26 \pm 10$ & 28 & $29 \pm 10$ & 16 & $27 \pm 13$ & 44 \\
\hline 111 & 96 & 96 & $33 \pm 13$ & 36 & $36 \pm 18$ & 19 & $35 \pm 19$ & 55 \\
\hline 0 & 192 & 192 & $52 \pm 17$ & 52 & $62 \pm 31$ & 34 & $57 \pm 34$ & 83 \\
\hline 222 & 192 & 192 & $50 \pm 21$ & 55 & $51 \pm 23$ & 27 & $50 \pm 25$ & 80 \\
\hline \multicolumn{3}{|c|}{$\mathrm{LSD}_{05}$} & 5.8 & 6.1 & 6.3 & 3.2 & 5.9 & 9.2 \\
\hline
\end{tabular}

Potassium cations $\left(\mathrm{K}^{+}\right)$bind quite strongly to the soil particles, large amounts of potassium are taken up by the plants, therefore potassium leaching rate is significantly lower than that of sodium or divalent cations. An average potassium concentration in lysimeter water sampled in winter at $40 \mathrm{~cm}$ depth in not fertilised plots was $0.86 \mathrm{mg} \mathrm{l}^{-1}$, in summer $-1.17 \mathrm{mg} \mathrm{l}^{-1}$. Leaching of potassium significantly depended on potassium fertilisation $\left(r^{2}=0.97, P>0.01\right)$. 
When test plots were fertilised with $96 \mathrm{~kg} \mathrm{ha}^{-1} \mathrm{~K}_{2} \mathrm{O}$ on the background of nitrogen and phosphorus fertilisation $(80 \mathrm{~kg}$ $\mathrm{ha}^{-1}$ of pure Kadded to the soil each year), $\mathrm{K}^{+}$concentration in lysimeter water sampled in winter at $40 \mathrm{~cm}$ depth increased by 0.89 , in summer $-0.54 \mathrm{mg} \mathrm{l}^{-1}$; when fertilisation rate was $192 \mathrm{~kg} \mathrm{ha}^{-1}\left(160 \mathrm{~kg} \mathrm{ha}^{-1}\right.$ of pure $\mathrm{K}$ added $)-3.56$ and $3.17 \mathrm{mg} \mathrm{l}^{-1}$, respectively (Table 6). The highest average concentration of potassium in lysimeter water $\left(5.57 \mathrm{mgl}^{-1}\right)$ was determined when crops were regularly treated with high phosphorus and potassium fertilisation rates but not treated with nitrogen - due to the low yields much smaller amounts of potassium were taken up by plants $\left(92.8 \mathrm{~kg} \mathrm{ha}^{-1}\right)$, thus potassium accumulated in the soil $\left(3.49 \mathrm{mmol}+\mathrm{kg}^{-1}\right)$, and larger amounts of it were leached. An average potassium leaching rate in not fertilised sandy loam soil at $40 \mathrm{~cm}$ depth was $0.93 \mathrm{~kg} \mathrm{ha}^{-1}$ in winter and $0.60 \mathrm{~kg} \mathrm{ha}^{-1}$ in summer; when soil was treated with $\mathrm{N}_{111} \mathrm{P}_{96} \mathrm{~K}_{96}$ and $\mathrm{N}_{222} \mathrm{P}_{192} \mathrm{~K}_{192}$ fertilisation rates, the leaching rates were 1.80 and 0.95 , and 4.54 and $2.42 \mathrm{~kg} \mathrm{ha}^{-1}$ of potassium, respectively. Since the potassium leaching rates were low, they had little effect on the potassium balance in soil. Askegaard and Eriksen (2000) indicated that in sandy loam soil the concentration of potassium in lysimeter water at $1 \mathrm{~m}$ depth was $0.6 \mathrm{mg} \mathrm{l}^{-1}$, leaching rate $1.5 \mathrm{~kg} \mathrm{ha}^{-1}$.

Table 6. The concentration of potassium $\left(\mathrm{K}^{+}\right)$in lysimeter water and leaching of potassium as affected by mineral fertilisation

Skèmiai, Radviliškis region, 1976-2011

\begin{tabular}{|c|c|c|c|c|c|c|c|c|c|}
\hline \multirow{2}{*}{\multicolumn{3}{|c|}{$\begin{array}{l}\text { Average fertilisation rate } \\
\qquad \mathrm{kg} \mathrm{ha}^{-1}\end{array}$}} & \multicolumn{2}{|c|}{ Winter } & \multirow{2}{*}{\multicolumn{2}{|c|}{ Summer }} & \multirow{2}{*}{\multicolumn{2}{|c|}{ Annual }} & \multirow{3}{*}{$\begin{array}{c}\text { Potassium } \\
\text { balance } \\
\mathrm{kg} \mathrm{ha}^{-1}\end{array}$} \\
\hline & & & \multicolumn{3}{|c|}{$\mathrm{K}^{+}$} & & & & \\
\hline $\mathrm{N}$ & $\mathrm{P}_{2} \mathrm{O}_{5}$ & $\mathrm{~K}_{2} \mathrm{O}$ & $\begin{array}{c}\text { concentration } \\
\mathrm{mg} \mathrm{l}^{-1}\end{array}$ & $\begin{array}{l}\text { leaching } \\
\mathrm{kg} \mathrm{ha}^{-1}\end{array}$ & $\begin{array}{c}\text { concentration } \\
\mathrm{mg} \mathrm{l}^{-1}\end{array}$ & $\begin{array}{l}\text { leaching } \\
\mathrm{kg} \mathrm{ha}^{-1}\end{array}$ & $\begin{array}{c}\text { concentration } \\
\mathrm{mg} \mathrm{l}^{-1}\end{array}$ & $\begin{array}{l}\text { leaching } \\
\mathrm{kg} \mathrm{ha}^{-1}\end{array}$ & \\
\hline \multicolumn{10}{|c|}{ at $40 \mathrm{~cm}$ depth } \\
\hline 0 & 0 & 0 & $0.86 \pm 0.58$ & 0.93 & $1.17 \pm 0.96$ & 0.60 & $1.05 \pm 0.97$ & 1.53 & -54.5 \\
\hline 0 & 96 & 96 & $2.24 \pm 2.01$ & 2.43 & $2.39 \pm 2.47$ & 1.24 & $2.32 \pm 2.38$ & 3.67 & -4.7 \\
\hline 111 & 0 & 96 & $2.00 \pm 1.77$ & 2.06 & $2.04 \pm 1.89$ & 1.06 & $2.02 \pm 1.94$ & 3.12 & -28.0 \\
\hline 111 & 96 & 0 & $0.77 \pm 0.66$ & 0.83 & $1.25 \pm 1.56$ & 0.65 & $1.05 \pm 1.41$ & 1.48 & -78.7 \\
\hline 111 & 96 & 96 & $1.66 \pm 2.60$ & 1.80 & $1.79 \pm 2.51$ & 0.95 & $1.73 \pm 2.55$ & 2.75 & -38.4 \\
\hline 0 & 192 & 192 & $4.47 \pm 5.01$ & 4.84 & $6.59 \pm 5.45$ & 3.53 & $5.57 \pm 3.07$ & 8.37 & 58.2 \\
\hline 222 & 0 & 192 & $3.24 \pm 2.43$ & 3.52 & $4.58 \pm 4.38$ & 2.51 & $4.02 \pm 4.20$ & 5.93 & 25.8 \\
\hline 222 & 192 & 0 & $0.63 \pm 0.44$ & 0.86 & $1.35 \pm 0.96$ & 0.71 & $1.00 \pm 0.90$ & 1.57 & -83.6 \\
\hline 222 & 192 & 192 & $4.19 \pm 5.00$ & 4.54 & $4.52 \pm 6.34$ & 2.42 & $4.38 \pm 6.03$ & 6.96 & -12.3 \\
\hline \multicolumn{3}{|c|}{$\mathrm{LSD}_{05}$} & 0.314 & 0.343 & 0.418 & 0.204 & 0.366 & 0.559 & \\
\hline \multicolumn{10}{|c|}{ at $80 \mathrm{~cm}$ depth } \\
\hline 0 & 0 & 0 & $0.44 \pm 0.31$ & 0.48 & $0.63 \pm 0.74$ & 0.33 & $0.55 \pm 0.55$ & 0.81 & -53.0 \\
\hline 111 & 96 & 96 & $1.06 \pm 1.00$ & 1.14 & $1.35 \pm 1.81$ & 0.71 & $1.21 \pm 1.71$ & 1.85 & -37.5 \\
\hline 0 & 192 & 192 & $2.96 \pm 2.92$ & 3.02 & $2.49 \pm 3.49$ & 1.19 & $2.75 \pm 5.61$ & 4.21 & 62.3 \\
\hline 222 & 192 & 192 & $0.68 \pm 0.46$ & 0.75 & $1.41 \pm 1.90$ & 0.73 & $1.06 \pm 1.60$ & 1.48 & -6.8 \\
\hline \multicolumn{3}{|c|}{$\mathrm{LSD}_{05}$} & 0.181 & 0.189 & 0.211 & 0.106 & 0.196 & 0.293 & \\
\hline
\end{tabular}

Tripolskaja and Romanovskaja (2010) indicate that during the 1972-1995 period of the experiment conducted on soils of different types, when crops were regularly treated with manure and mineral fertilisers, an average annual potassium leaching rate was up to $13.943 .4 \mathrm{~kg} \mathrm{ha}^{-1}$ in light loam soil and up to $43.4 \mathrm{~kg}$ $\mathrm{ha}^{-1}$ in loamy sand. We processed the data obtained from our experiments and found that an average annual

Table 7. The concentration of sodium $\left(\mathrm{Na}^{+}\right)$in lysimeter water and leaching of sodium as affected by mineral fertilisation

Skėmiai, Radviliškis region, 1976-2011

\begin{tabular}{|c|c|c|c|c|c|c|c|c|}
\hline \multirow{2}{*}{\multicolumn{3}{|c|}{$\begin{array}{l}\text { Average fertilisation rate } \\
\mathrm{kg} \mathrm{ha}^{-1}\end{array}$}} & \multirow{2}{*}{\multicolumn{2}{|c|}{ Winter }} & \multicolumn{2}{|c|}{ Summer } & \multicolumn{2}{|c|}{ Annual } \\
\hline & & & & & \multicolumn{2}{|c|}{$\mathrm{Na}^{+}$} & & \\
\hline $\mathrm{N}$ & $\mathrm{P}_{2} \mathrm{O}_{5}$ & $\mathrm{~K}_{2} \mathrm{O}$ & $\begin{array}{c}\text { concentration } \\
\mathrm{mg} \mathrm{l}^{-1}\end{array}$ & $\begin{array}{l}\text { leaching } \\
\mathrm{kg} \mathrm{ha}^{-1}\end{array}$ & $\begin{array}{c}\text { concentration } \\
\mathrm{mg} \mathrm{l}^{-1}\end{array}$ & $\begin{array}{l}\text { leaching } \\
\mathrm{kg} \mathrm{ha}^{-1}\end{array}$ & $\begin{array}{c}\text { concentration } \\
\mathrm{mg} \mathrm{l}^{-1}\end{array}$ & $\begin{array}{l}\text { leaching } \\
\mathrm{kg} \mathrm{ha}^{-1}\end{array}$ \\
\hline \multicolumn{9}{|c|}{ at $40 \mathrm{~cm}$ depth } \\
\hline 0 & 0 & 0 & $3.22 \pm 1.56$ & 3.83 & $2.87 \pm 1.02$ & 1.46 & $3.01 \pm 1.27$ & 5.29 \\
\hline 0 & 96 & 96 & $4.24 \pm 2.37$ & 5.01 & $4.39 \pm 2.30$ & 2.18 & $4.32 \pm 2.43$ & 7.19 \\
\hline 111 & 0 & 96 & $4.08 \pm 1.63$ & 5.40 & $4.98 \pm 1.73$ & 2.48 & $4.60 \pm 1.91$ & 7.88 \\
\hline 111 & 96 & 0 & $3.71 \pm 2.05$ & 4.38 & $3.09 \pm 1.06$ & 1.56 & $3.35 \pm 1.50$ & 5.94 \\
\hline 111 & 96 & 96 & $3.92 \pm 2.04$ & 4.67 & $4.20 \pm 2.32$ & 2.15 & $4.08 \pm 2.36$ & 6.82 \\
\hline 0 & 192 & 192 & $6.27 \pm 2.76$ & 7.61 & $6.07 \pm 2.40$ & 3.12 & $6.16 \pm 2.65$ & 10.73 \\
\hline 222 & 0 & 192 & $6.49 \pm 2.29$ & 7.67 & $6.65 \pm 2.59$ & 3.39 & $6.59 \pm 2.78$ & 11.06 \\
\hline 222 & 192 & 0 & $2.75 \pm 1.41$ & 3.33 & $3.15 \pm 1.21$ & 1.60 & $2.98 \pm 1.44$ & 4.93 \\
\hline 222 & 192 & 192 & $4.88 \pm 2.42$ & 5.76 & $6.12 \pm 3.33$ & 3.18 & $5.79 \pm 3.35$ & 8.94 \\
\hline \multicolumn{3}{|c|}{$\mathrm{LSD}_{05}$} & 0.625 & 0.753 & 0.663 & 0.349 & 0.646 & 1.087 \\
\hline \multicolumn{9}{|c|}{ at $80 \mathrm{~cm}$ depth } \\
\hline 0 & 0 & 0 & $3.34 \pm 1.82$ & 3.95 & $3.31 \pm 1.31$ & 1.67 & $3.32 \pm 1.59$ & 5.62 \\
\hline 111 & 96 & 96 & $3.89 \pm 1.93$ & 4.63 & $3.77 \pm 1.08$ & 1.91 & $3.82 \pm 1.54$ & 6.54 \\
\hline 0 & 192 & 192 & $8.21 \pm 5.00$ & 8.95 & $7.32 \pm 2.50$ & 3.72 & $7.77 \pm 3.69$ & 12.67 \\
\hline 222 & 192 & 192 & $4.95 \pm 2.33$ & 5.73 & $5.13 \pm 2.49$ & 2.56 & $5.04 \pm 2.57$ & 8.29 \\
\hline \multicolumn{3}{|c|}{$\mathrm{LSD}_{05}$} & 0.732 & 0.836 & 0.709 & 0.357 & 0.702 & 1.167 \\
\hline
\end{tabular}


concentration of potassium in lysimeter water at $80 \mathrm{~cm}$ depth was twice as low as that at $40 \mathrm{~cm}$ depth in summer (due to an intensive uptake of potassium by plants) and by 1.5 times - in winter. Sodium levels in the soil arable layer are lower than those of potassium, yet an uptake of sodium by plants is lower as well, therefore larger amounts of sodium are leached from the upper layers of soil. There was significant relationship $\left(r^{2}=0.91, P>0.01\right)$ between the concentration of sodium in soil solution and potassium fertilisation. Potassium fertiliser (potassium chloride) contains low levels of sodium, approximately $1.8 \%$; still the long-term regular application of potassium fertiliser increased the concentration of sodium in lysimeter water. On an average for 1976-2011, when crops were treated with $96 \mathrm{~kg} \mathrm{ha}^{-1}$ potassium fertilisation rate on the background of $\mathrm{N}_{111} \mathrm{P}_{96}$, the concentration of potassium at $40 \mathrm{~cm}$ depth increased by $0.21 \mathrm{mg} \mathrm{l}^{-1}$ in winter and by $1.11 \mathrm{mg} \mathrm{l}^{-1}$ in summer; when crops were treated with $192 \mathrm{~kg} \mathrm{ha}^{-1}$ potassium fertilisation rate the concentrations of potassium were 2.13 and $2.97 \mathrm{mg} \mathrm{l}^{-1}$, respectively (Table 7). Nitrogen and phosphorus fertilisers had little effect on sodium leaching rate $\left(r^{2}=0.12\right.$ and $r^{2}=0.31$, $P>0.05)$; somewhat higher concentration of sodium in lysimeter water was determined when crops were not treated with phosphorus.

Sodium leaching rate during the cold period of the year was by 1.8 times higher than in summer. The largest annual amounts of leached sodium (10.73 and $11.06 \mathrm{~kg} \mathrm{ha}^{-1}$ ) were determined when crops were regularly treated with phosphorus and potassium fertilisers but not treated with nitrogen, and - with nitrogen and potassium fertilisers but not treated with phosphorus. The data obtained by Tripolskaja and Romanovskaja (2010) suggests that sodium leaching rate depends on soil type and texture and is within the range $11.9-53.6 \mathrm{~kg} \mathrm{ha}^{-1}$. An average annual concentration of sodium in lysimeter water at $80 \mathrm{~cm}$ depth was similar to that at $40 \mathrm{~cm}$ depth - the amounts of sodium taken up by plants are rather small, therefore sodium is leached into the deeper layers of soil more intensively.

\section{Conclusions}

The study of the effects of long-term (1971-2011) mineral fertilisation on the migration of cations $\mathrm{Ca}^{2+}, \mathrm{Mg}^{2+}$, $\mathrm{K}^{+}$and $\mathrm{Na}^{+}$in calcaric sandy loamy soil concluded:

1. Calcium leaching of was the most intensive, followed by that of magnesium; sodium and potassium leaching was significantly less. As a result of application of the $\mathrm{N}_{111} \mathrm{P}_{96} \mathrm{~K}_{96}$ fertilisation rates the sum of average concentrations of the base cations $\mathrm{Ca}^{2+}, \mathrm{Mg}^{2+}, \mathrm{Na}^{+}$and $\mathrm{K}^{+}$in lysimeter water at $40 \mathrm{~cm}$ depth was $179.58 \mathrm{mg} \mathrm{l}^{-1}$ in winter and $218.99 \mathrm{mg} \mathrm{l}^{-1}$ in summer (calcium - 145 and $180 \mathrm{mg} \mathrm{l}^{-1}$, magnesium - 29 and $33 \mathrm{mg} \mathrm{l}^{-1}$, sodium -3.92 and $4.20 \mathrm{mg} \mathrm{l}^{-1}$, potassium - 1.66 and $1.79 \mathrm{mg} \mathrm{l}^{-1}$, respectively).

2. Calcium leaching processes were stimulated by the mineral fertilisation. Average fertilisation rates $\left(\mathrm{N}_{111} \mathrm{P}_{96} \mathrm{~K}_{96}\right)$ increased the concentration of $\mathrm{Ca}^{2+}$ in lysimeter water by 1.4 times in winter and by 1.5 times in summer, while high rates $\left(\mathrm{N}_{222} \mathrm{P}_{192} \mathrm{~K}_{192}\right)-$ by 1.9 and 2.2 times, respectively. High rates of mineral fertilisation resulted in 232-360 kg ha-1 $\mathrm{Ca}^{2+}$ leached into the deeper soil layers each year. Phosphorus fertilisation makes the calcium balance in soil less negative, while nitrogen and potassium fertilisation encourages the process of calcium leaching.

3 . The extent of magnesium leaching from the soils treated with mineral fertilisers was within the range of 31-56 $\mathrm{kg} \mathrm{ha}^{-1} \mathrm{Mg}^{2+}$ in winter and $17-30 \mathrm{~kg} \mathrm{ha}^{-1} \mathrm{Mg}^{2+}$ in summer. Average and high fertilisation rates increased the level of magnesium leaching by $12 \mathrm{~kg} \mathrm{ha}^{-1} \mathrm{Mg}^{2+}$ in winter and $7 \mathrm{~kg} \mathrm{ha}^{-1} \mathrm{Mg}^{2+}$ in summer, and $33 \mathrm{~kg} \mathrm{ha}^{-1} \mathrm{Mg}^{2+}$ in winter and $18 \mathrm{~kg} \mathrm{ha}^{-1} \mathrm{Mg}^{2+}$ in summer, respectively.

4. Small amounts of potassium were leached into the $40 \mathrm{~cm}$ depth of light loamy soil: in not fertilised plots $0.93 \mathrm{~kg} \mathrm{ha}^{-1} \mathrm{~K}^{+}$in winter and $0.60 \mathrm{~kg} \mathrm{ha}^{-1} \mathrm{~K}^{+}$in summer, in plots treated with $\mathrm{N}_{111} \mathrm{P}_{96} \mathrm{~K}_{96}$ and $\mathrm{N}_{222} \mathrm{P}_{192} \mathrm{~K}_{192}-1.80$ and 0.95 , and 4.54 and $2.42 \mathrm{~kg} \mathrm{ha}^{-1} \mathrm{~K}^{+}$, respectively. Low levels of potassium leaching had little effect on potassium balance in the soil.

5. Sodium leaching level did not exceed $7.67 \mathrm{~kg} \mathrm{ha}^{-1}$ $\mathrm{Na}^{+}$in winter and $3.39 \mathrm{~kg} \mathrm{ha}^{-1} \mathrm{Na}^{+}$in summer. Application of mineral fertilisers resulted in sodium leaching increase by $5.77 \mathrm{~kg} \mathrm{ha}^{-1} \mathrm{Na}^{+}$on an average; potassium fertilisation encouraged the process of sodium leaching.

6. As a result of intensive fertilisation, the concentrations of calcium and magnesium ions in lysimeter water sampled at $80 \mathrm{~cm}$ depth were slightly higher than those in the lysimeter water at $40 \mathrm{~cm}$ depth, the concentration of potassium ions - lower, and the concentration of sodium ions - about the same.

\section{Acknowledgements}

Our research activities were supported by the Ministry of Agriculture and the Ministry of Education and Science. We give our thanks to the Head Algirdas Venckus and Chief Agronomist Rimantas Kadzys of Skèmiai Agricultural Company.

Received 05072012 Accepted 02042013

\section{References}

Aitken R. L., Scott B. J. 1999. Magnesium. Soil analysis: an interpretation manual / Peverill K. I. et al. (eds). Collingwood, Australia, p. 255-262

Alfaro M. A., Jarvis S. C., Gregory P. J. 2004. Factors affecting potassium leaching in different soils. Soil Use and Management. 20: 182-189 http://dx.doi.org/10.1079/SUM2004249

Askegaard M., Eriksen J. 2000. Potassium retention and leaching in an organic crop rotation on loamy sand as affected by contrasting potassium budgets. Soil Use and Management. 16: 200-205 http://dx.doi.org/10.1111/j.1475-2743.2000.tb00193.x

Baigys G., Gaigalis K. 2012. Influence of land tillage methods on drainage runoff and nitrogen migration. Vandens ūkio inžinerija, 40 (60): 83-93 (in Lithuanian)

Barber S. A. 1984. Soil chemistry and the availability of plant nutrients. Chemistry in the soil environment: special publication No. 40. Madison, USA, p. 382-409

Bruce R. C. 1999. Calcium. Soil analysis: an interpretation manual / Peverill K. I. et al. (eds). Collingwood, Australia, p. $247-254$

Clewer A. G., Scarisbrick D. H. 2001. Practical statistics and experimental design for plant and crop science

Erickson J. E., Cisar J. L., Snyder G. H., Volin J. C. 2005. Phosphorus and potassium leaching under contrasting residential landscape models established on a sandy soil. Crop Science, 45: 546-552 http://dx.doi.org/10.2135/cropsci2005.0546

Kadūnas V., Gudavičius R., Gregorauskienè V., Katinas V., Kliaugienè E., Radzevičius A., Taraškevičius R. 1999. Geochemical atlas of Lithuania. Vilnius, 253 p. (in Lithuanian)

Kolahchi Z., Jalali M. 2007. Effect of water quality on the leaching of potassium from sandy soil. Arid Environments, 68: 624-639 http://dx.doi.org/10.1016/j.jaridenv.2006.06.010 
Končius D., Ožeraitienė D., Piaulokaitè-Motuzienė L., Katutis K. 2008. The effect of long-term antropogenic load on the properties of Albeluvisol. Vagos, 80 (33): 33-39 (in Lithuanian)

Levy R., Feigenbaum S. 1997. Effect of dilution on soluble and exchangeable sodium in soils differing in mineralogy. Geoderma, 18: 193-205

http://dx.doi.org/10.1016/0016-7061(77)90062-3

Mašauskas V., Mašauskienè A. 2010. Management of agroecosystem components. Results of long-term agrochemical experiments: a monograph / compiled by Tripolskaja L. et al. Lithuanian Research Centre of Agriculture and Forestry, p. 318-320 (in Lithuanian)

Mažvila J. 1998. Agrochemical properties of Lithuanian soils and their change: a monograph / compiled by Mažvila J. Lithuanian Institute of Agriculture, p. 37-49 (in Lithuanian)

Mesič M., Kisič I., Bašič F., Butorac A., Zgorelec Ž., Gašpar I. 2007. Losses of $\mathrm{Ca}, \mathrm{Mg}$ and $\mathrm{SO}_{4}^{2-} \mathrm{S}$ with drainage water at fertilisation with different nitrogen rates. Agriculturae Conspectus Scientificus, 72 (1): 53-58

Oliveira M. W., Trivelin P. C. O., Boaretto A. E., Muraoka T., Mortatti J. 2002. Leaching of nitrogen, potassium, calcium and magnesium in a sandy soil cultivated with sugarcane. Pesquisa Agopecuaria Brasileira. 37 (6): 1-7 http://dx.doi.org/10.1016/0016-7061(77)90062-3

Poss R., Saragoni H. 1992. Leaching of nitrate, calcium and magnesium under maize cultivation on an oxisol in Togo. Fertilizer Research. 33: 123-133 http://dx.doi.org/10.1007/BF01051167
Tyla A., Rim elis J., leinys R. 1997. Leaching of nutrient matter of plants in different soils. Lithuanian Institute of Agriculture, 25 p. (in Lithuanian)

Tripolskaja L. 2005. Organic fertilisers and their effect on the environment: a monograph. Lithuanian Institute of Agriculture, 216 p. (in Lithuanian)

Tripolskaja L., Janušiené V. 2010. Management of agroecosystem components. Results of long-term agrochemical experiments: a monograph / compiled by Tripolskaja L. et al. Lithuanian Research Centre of Agriculture and Forestry, p. 282-288 (in Lithuanian)

Tripolskaja L., Romanovskaja D. 2010. Management of agroecosystem components. Results of long-term agrochemical experiments: a monograph / compiled by Tripolskaja L. et al. Lithuanian Research Centre of Agriculture and Forestry, p. 288-303 (in Lithuanian)

Мотузова Г. В., Барсова Н. Ю., Карпова Е. А., Кочарян А. Г. 2009. Состав лизиметрических вод почв верхневолжских ландшафтов. Почвоведение, 2: 226-234 (in Russian)

Патыка Н. В., Бердников А. М., Патыка В. Ф. 2009. Миграция питательных элементов и гумуса подзолистой почвы в условиях длительных лизиметрических опытов. Агрохимия и грунтознавство, 72: 60-66 (in Russian)

Хомяков В. Н. 1989. Объективная оценка состояния агроценоза: агрометеорологический аспект. Ленинград, c. 126-130 (in Russian)

Шилова Е. И. 1955. Метод получения почвенного раствора в природных условиях. Почвоведение, 11: 48-61 (in Russian)

ISSN 1392-3196 / e-ISSN 2335-8947

Zemdirbyste-Agriculture, vol. 100, No. 2 (2013), p. 119-126

DOI $10.13080 / \mathrm{z}-\mathrm{a} .2013 .100 .015$

\title{
Bazinių katijonų išplovimas keturis dešimtmečius tręšiant mineralinėmis trąšomis
}

\author{
T. Adomaitis, G. Staugaitis, J. Mažvila, Z. Vaišvila, J. Arbačiauskas, J. Lubyte, D. Šumskis, \\ A. Švėgžda
}

Lietuvos agrarinių ir miškų mokslų centro Agrocheminių tyrimų laboratorija

\section{Santrauka}

Tyrimai atlikti Vidurio Lietuvoje (Radviliškio r., Skèmiuose) 1971 m. ịrengto (lizimetrai įrengti 1976 m.) ilgalaikio sẻjomaininio bandymo smèlingo lengvo priemolio giliau karbonatingame giliau glèjiškame rudžemyje (RDg4-k2), siekiant nustatyti ịvairių normų NPK trąšų ir jų derinių ịtaką katijonų $\left(\mathrm{Ca}^{2+}, \mathrm{Mg}^{2+}, \mathrm{K}^{+}, \mathrm{Na}^{+}\right)$išplovimui. Tirta sistemingo tręšimo skirtingomis normomis NPK trąšu ịtaka $\mathrm{Ca}^{2+}, \mathrm{Mg}^{2+}, \mathrm{K}^{+}$bei $\mathrm{Na}^{+}$koncentracijai lizimetru vandenyje (40 ir $80 \mathrm{~cm}$ gylyje) žiemą ir vasarą. 1976-2011 m. laikotarpiu iš dirvožemio daugiausia išplauta kalcio, mažiau - magnio, žymiai mažiau natrio ir mažiausiai - kalio. Augalus patręšus $\mathrm{N}_{111} \mathrm{P}_{96} \mathrm{~K}_{96}$ trąšomis, mainų katijonų $\mathrm{Ca}^{2+}, \mathrm{Mg}^{2+}, \mathrm{Na}^{+}$ir $\mathrm{K}^{+}$vidutinès koncentracijos suma $40 \mathrm{~cm}$ gylio lizimetrų vandenyje žiemą buvo 179,58 $\mathrm{mg} \mathrm{l}^{-1}$, vasarą $-218,99 \mathrm{mg} \mathrm{l}^{-1}$, iš jų atitinkamai kalcio -145 ir $180 \mathrm{mg} \mathrm{l}^{-1}$, magnio -29 ir $33 \mathrm{mg} \mathrm{l}^{-1}$, natrio $-3,92$ ir 4,20 $\mathrm{mg} \mathrm{l}^{-1}$, kalio - 1,66 ir $1,79 \mathrm{mg} \mathrm{l}^{-1}$. Ca ${ }^{2+}$ koncentracija lizimetrų vandenyje nuo vidutinių $\left(\mathrm{N}_{111} \mathrm{P}_{96} \mathrm{~K}_{96}\right)$ normų trąšu žiemą padidèjo 1,4 , vasarą - 1,5, o nuo didelių $\left(\mathrm{N}_{222} \mathrm{P}_{102} \mathrm{~K}_{102}\right)$ - atitinkamai 1,9 ir 2,2 karto. Tręštame dirvožemyje kasmet ị gilesnius sluoksnius išplauta nuo $232 \mathrm{iki} 360 \mathrm{~kg} \mathrm{ha}^{-1} \mathrm{Ca}^{2+}$. Fosforo trąšos mažino neigiamą kalcio balansą dirvožemyje. Augalus skirtingai patręšus mineralinèmis trąšomis, magnio iš 1 ha žiemą išplauta $31-56 \mathrm{~kg} \mathrm{Mg}^{2+}$, vasarą - 17-30 $\mathrm{kg} \mathrm{Mg}^{2+}$. Dèl vidutinių ir didelių normų trąšų ịtakos jo išplovimas padidejo maždaug 1,5 ir 2,5 karto. Iš lengvo priemolio dirvožemio ị $40 \mathrm{~cm}$ gyli kalio išplauta labai mažai: netręštame dirvožemyje žiemą maždaug $0,93 \mathrm{~kg} \mathrm{ha}^{-1} \mathrm{~K}^{+}$, vasarą $-0,60 \mathrm{~kg} \mathrm{ha}^{-1} \mathrm{~K}^{+}$, tręštame $\mathrm{N}_{111} \mathrm{P}_{96} \mathrm{~K}_{96}$ ir $\mathrm{N}_{222} \mathrm{P}_{192} \mathrm{~K}_{192}$ - atitinkamai 1,80 bei 0,95 ir 4,54 bei $2,42 \mathrm{~kg} \mathrm{ha}^{-1} \mathrm{~K}^{+}$. Maži išplauto kalio kiekiai jo balansui dirvožemyje turèjo nedidelę įtaką. Natrio nevegetacijos laikotarpiu išplauta iki $7,67 \mathrm{~kg} \mathrm{ha}^{-1} \mathrm{Na}^{+}$, vegetacijos - iki $3,39 \mathrm{~kg} \mathrm{ha}^{-1} \mathrm{Na}^{+}$. Nuo trąšu per metus jo išplovimas padidèjo vidutiniškai $5,77 \mathrm{~kg} \mathrm{ha}^{-1} \mathrm{Na}^{+}$, ir ji labiausiai skatino kalio trąšos.

Giliau ( $80 \mathrm{~cm}$ gylyje), palyginti su $40 \mathrm{~cm}$ gyliu, kai augalai buvo gausiau tręšti, lizimetrų vandenyje kalcio ir magnio jonų koncentracija buvo nežymiai didesnè, kalio, priešingai, giliau buvo mažesnè, o natrio abiejuose dirvožemio gyliuose buvo panaši.

Reikšminiai žodžiai: dirvožemis, $\mathrm{Ca}^{2+}, \mathrm{Mg}^{2+}, \mathrm{K}^{+}, \mathrm{Na}^{+}$koncentracija, lizimetrai, NPK trąšos. 